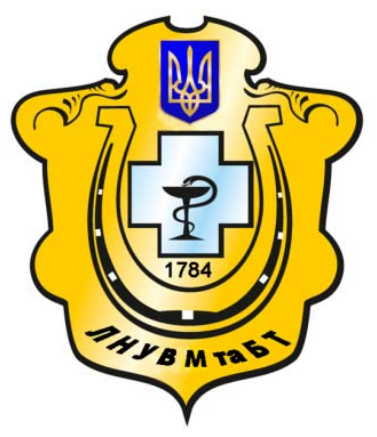

Науковий вісник Львівського національного університету ветеринарної медицини та біотехнологій імені С.3. Гжицького

Scientific Messenger of Lviv National University of Veterinary Medicine and Biotechnologies named after S.Z. Gzhytskyj

doi:10.15421/nvlvet7138

ISSN 2413-5550 print

ISSN 2518-1327 online

$\underline{\text { http://nvlvet.com.ua/ }}$

УДК 619:616.1:616.07:636.1

\title{
Поширення і характеристика серцевих шумів у спортивних коней
}

\author{
I.А. Максимович \\ maksym_vet@ukr.net
}

Львівський національний університет ветеринарної медицини та біотехнологій імені С.3. Гжиџького, вул. Пекарська, 50, м. Львів, 79010, Украӥна

\begin{abstract}
У статті висвітлено результати досліджень поширення серцевих шумів у спортивних коней та їх вплив на працездатність тварин. Дослідження проводилися на конях української верхової, ганноверської та вестфальської і англійської чистокровної порід, щео використовуються в класичних видах кінного спорту.

Клінічні дослідження включали вимірювання температури тіла, підрахунок частоти пульсу та дихання, артеріального пульсу, серцевого поштовху, тонів і шумів серия. Критеріями оцінки серцевих шумів були: час появи, локалізачія, інтенсивність, приналежність до фаз сериевої діяльності (систола чи діастола). Серчеві шуми оцінювали за шкалою від 1 до 6. Дослідження проводилися у стані спокою та не раніше 2 годин після фізичного навантаження.

Сериеві шуми реєстрували у 64\% спортивних коней, проте більшість із них не мали клінічного значення, оскільки лише у 6,7\% досліджених тварин була знижена працездатність. Частіше реєстрували систолічні шуми (в р.орt. мітрального клапана - у 20\% коней; тристулкового клапана - 24\%; над легеневою артерією - 8\%; клапанів аорти - у 4\% тварин), рідше діастолічні (в р.орt. клапанів аорти - у $8 \%$ коней).

Ключові слова: коні, аускультачія, сериеві шуми, клапанна регургітація, ехокардіографія.
\end{abstract}

\section{Распространение и характеристика сердечных шумов у спортивных лошадей}

\author{
И.А. Максимович \\ maksym_vet@ukr.net
}

Львовский национальный университет ветеринарной медицины и биотехнологий имени С.3. Гжицкого, ул. Пекарская, 50, г. Львов, 79010, Украина

В статье представлены результаты исследований распространения сердечных шумов у спортивных лошадей и их влияние на работоспособность животных. Исследования проводились на лошадях украинской верховой, ганноверской и вестфальской а также английской чистокровной пород используемыхх в классических видах конного спорта.

Клинические исследования включали измерения температуры тела, частоты пульса и дыхания, артериального пульса, сердечного толчка, тонов и шумов сердия. Критериями оценки сердечных шумов были: время появления, локализачия, интенсивность, принадлежность к фазам сердечной деятельности (систола или диастола). Сердечные шумы оценивали по шкале от 1 до 6. Исследования проводились в состоянии покоя и не ранее 2-х часов после физической нагрузки.

Сердечные шумы регистрировали у 64\% спортивных лошадей, однако большинство из них не имели клинического значения, поскольку только в 6,7\% исследованных животных была снижена работоспособность. Чаще регистрировали систолические шумы (в р.орt. митрального клапана - у 20\% лошадей; трехстворчатого клапана - 24\%, над легочной артерией8\%; клапанов аорты - у 4\% животных), реже диастолические (в р.орt. клапанов аорть - в 8\% лотадей).

Ключевые слова: лочади, аускультачия, сердечные шумы, клапанная регургитачия, эхокардиография.

Citation:

Maksymovych, I.A. (2016). Prevalence and characteristics heart murmurs in sport horses. Scientific Messenger LNUVMBT named after S.Z. Gzhytskyj, 18, 3(71), 170-173. 


\title{
Prevalence and characteristics heart murmurs in sport horses
}

\author{
I.A. Maksymovych \\ maksym_vet@ukr.net \\ Lviv National University of Veterinary Medicine and Biotechnologies named after S.Z. Gzhytskyi, \\ Pekarska Str., 50, Lviv, 79010, Ukraine
}

The paper presents the research results dissemination heart murmurs among sport horses and their impact on the performance of the animals. The studies were conducted on horses Ukrainian, Hanoverian and Westphalian warmblood and English thoroughbred breed used in classical equestrian sport.

The clinical studies included measurements of body temperature, counting pulse rate and breathing, rate, cardiac shock, cardiac tones and murmurs. The criteria for evaluation of heart murmurs were: time of appearance, location, intensity, belonging to the cardiac phase (systole or diastole). Heart murmurs evaluated on a scale of 1 to 6. The studies were conducted at rest and not earlier than 2-hours after exercise.

Heart sounds were recorded in $64 \%$ of sport horses, but most of them had no clinical significance since only $6.7 \%$ of the studied animals was reduced performance. Most recorded systolic murmurs (mitral valve-20\% of horses, tricuspid valve - 24\%, pulmonary artery $-8 \%$, aortic valve $-4 \%$ of the animals), rarely diastolic (aortic valve - $8 \%$ of horses).

Our studies suggest that the prevalence of heart murmurs in sport horses depends on the age of the animals, exercise, functional and morphological changes valvular heart caused by constant exposure to sports training and more. However, to confirm these findings required further investigation.

Key words: horses, auscultation, heart murmurs, valve regurgitation, echocardiography.

\section{Вступ}

Еволюція зробила коня винятковим спортсменом, який виживав завдяки швидкості, щоб захиститись від хижаків, витривалості для подолання значних відстаней у пошуку корму і води. В сьогоденні людина використовує ці характеристики коней в різних умовах, зокрема у спорті (Ricketts, 2004).

Вага серця дорослого коня масою 450 кг складає 4,5 кг. За одне скорочення воно виштовхує біля 1,3 л крові, а під час навантаження ударний об'єм збільшується на 20-50\%. У стані спокою серцевий викид у коней складає 25-40 л крові за 1 хв, тоді як під час максимального навантаження у кров'яне русло виштовхується до 300 л крові.

На відміну від людей в яких харчування і фізичне навантаження можуть сприяти розвитку серцевосудинних захворювань, у коней не реєструються атеросклеротичні зміни судин, що призводять до інсульту чи інфаркту. Оскільки коней утримують для виконання фізичної роботи або використовують у спорті, зокрема і їзда верхи, наслідки будь-якого серцевосудинного захворювання несуть небезпеку для наїзника. При виборі напрямку використання коня необхідно враховувати вплив серцевої патології на продуктивність тварини та безпеку для людей. Більшість хвороб серця у коней, за винятком вроджених вад, розвиваються 3 віком, так само, як у людей, собак i котів.

Визначення впливу серцево-судинних розладів на продуктивність і тривалість життя коня має першочергове значення. Комплексне дослідження серцевосудинної системи є важливим для виявлення патології і є загальним підходом до оцінки серцевих розладів. Діагностика, оцінка, характеристика та прогнозування серцевих шумів розглядаються для кожної серцевосудинної патології. У той час як більшість коней 3 серцевими порушеннями мають термін корисного використання, у коней із захворюваннями, що супроводжуються клінічною симптоматикою необхідно проводити повторні дослідження. Коні з легеневою гіпертензією, ХСН або складними шлуночковими аритміями не повинні використовуватися у спорті (Reef et al., 2014).

Серцеві шуми часто реєструються в споривних коней. Слід зазначити, що фізіологічні шуми, які досить поширені у коней, інколи важко відрізнити від шумів, пов'язаних з основною хворобою серця (Reef, 1995).

Знання механізму розвитку серцево-судинних захворювань, в поєднанні з історією хвороби та заключення ехокардіографії, може допомогти сформувати прогноз щодо життя і працездатності коней з серцевими шумами (Davis et al., 2002).

Результати досліджень показують, що серцеві шуми у спортивних коней не мають клінічного значення (Kriz et al., 2000) або їх вплив на спортивні результати невідомий (Young et al., 2008).

Ряд авторів (Martin et al., 2000) стверджують, що серцеві шуми у коней, які не супроводжуються клінічними симптомами вважаються фізіологічними. Інші автори (Zucca et al., 2010) підкреслюють, що серцеві шуми часто реєструються в спортивних коней з низькою продуктивністю.

Метою роботи було дослідити поширення серцевих шумів серед спортивних коней та встановити їх клінічне значення.

\section{Матеріал і методи досліджень}

Матеріалом для досліджень було 75 коней, що використовуються в класичних видах кінного спорту української верхової, ганноверської та вестфальської і англійської чистокровної порід. Серед дослідних тварин було 36 кобил, 12 жеребців і 27 меринів. Вік коней складав у середньому $8,2 \pm 0,4$ p. $(3,0-16,0$ р.), вага $-490,1 \pm 8,28$ кг $(350-600$ кг $)$.

Добовий раціон коней складав: сіно лугове (6 кг), овес (6 кг), пшеничні висівки (2 кг), розподілений три рази на день. Сіль і вода були доступні без обмежень. 
В усіх коней було досліджено загальний аналіз крові та основні біохімічні показники, що характеризують функціональний стан органів і систем, які знаходилися в межах референтних коливань. Кобили не були жеребними. Всі коні були дегельмінтизовані та вакциновані, знаходилися в однакових умовах утримання.

Тривалість регулярних тренувань середньої інтенсивності складала 1 годину: крок 5 хв.; стройова рись 10 хв.; крок 5 хв.; учбова рись 10 хв.; крок 10 хв.; галоп 3 переходом в крок 10 хв.; крок 10 хв. Всі коні знаходяться в регулярному навчанні протягом багатьох років.

Аускультацію серця проводили в місцях найкращого вислуховування клапанів (puncta optima, p.opt.) 3 метою вислуховування тонів серця. Звертали увагу на силу, тембр, чіткість, частоту та ритм серцевих тонів, наявність шумів. Критеріями оцінки серцевих шумів були: час появи, локалізація, інтенсивність, приналежність до фаз серцевої діяльності (систола чи діастола).

Серцеві шуми оцінювали за шкалою від 1 до 6: 1/6 - дуже тихий локалізований шум, що вислуховується тільки в тихому приміщенні після тривалої аускультації (у перші кілька секунд не вислуховується); 2/6 тихий локалізований шум, який вислуховується відразу при аускультації; 3/6 - помірно голосний шум 3 дещо вираженим при пальпації тремтінням грудної стінки; 4/6 - голосний шум 3 пальпаторно вираженим тремтінням; 5/6 - дуже голосний шум 3 вираженим широким тремтінням грудної стінки, що вислуховується за допомогою стетоскопу при нещільному контакті з грудною кліткою; 6/6 - дуже голосний шум 3 широкою іррадіацією, який вислуховується стетоскопом на відстані від грудної клітки або чутний без нього (Kriz et al., 2000).

Дослідження проводилися у стані спокою та не раніше 2-ох годин після фізичного навантаження.

\section{Результати та їх обговорення}

Проведені дослідження показали, що у 6 коней (8\%) реєструвалася тахікардія (> 42 ударів за хвилину), у 9 (12\%) - тахіпное (>16 дихальних рухів на хвилину). Температура тіла знаходилася у межах фізіологічних коливань $\left(37,4-38,0{ }^{\circ} \mathrm{C}\right)$. У 2 коней (2,7\%) реєструвалася задишка, у $5(6,7 \%)$ - зниження працездатності.

Незважаючи на всі передові методи дослідження і діагностичні можливості, що використовуються у ветеринарній медицині, частота серцевих скорочень продовжує залишатися одним 3 кращих прогностичних ознак, пов'язаних з захворюваннями серця у коней.

Аускультація є специфічним і досить чутливим методом для виявлення мітральної і трикуспідальної регургітації (мітральна регургітація: позитивна прогностична цінність $100 \%$, негативна прогностична цінність 84\%, трикуспідальна регургітація: позитивна прогностична цінність 100\%, негативна прогностична цінність 65\%). Дослідженнями показано (Young and Wood, 2000), що існує вплив спортивної підготовки на розвиток атріовентрикулярної клапанної регургітації в чистокровних коней. Також встановлено, що з віком серед чистокровних коней збільшується частота серцевих шумів (Stevens et al., 2009).

Під час аускультації серця у здорових коней можна вислуховувати від двох до чотирьох тонів. Перший серцевий тон (Т1) співпадає з початком автоматичної систоли шлуночків, а його основним звуковим компонентом є закриття атріовентрикулярних клапанів. Другий тон (Т2) пов'язаний із закриттям півмісяцевих клапанів та їх вібрацією, що викликана раптовим зворотнім током крові на початку діастоли.

У здорових коней можуть вислуховуватися додаткові третій (Т3) та четвертий (Т4) тони серця, що реєструються під час діастоли. Т3 вислуховується відразу після Т2 і виникає внаслідок швидкого наповнення шлуночків.

T4 виникає під час активної систоли передсердь, безпосередньо перед першим тоном. Він обумовлений ударом порції крові з передсердя об верхній фронт крові, що наповнила шлуночок під час попередніх фаз швидкого i повільного наповнення. Також стінки шлуночків максимально розтягуються кров'ю, яка надходить в них, що супроводжується невеликим підвищенням внутрішньошлуночкового тиску. Ефект вібрації розтягнутих шлуночків викликає коливання кардіогемічної системи (передсердь і шлуночків 3 вміщеною в них кров’ю) (Robinson, 2007).

Нашими дослідженнями встановлено послаблення серцевих тонів у 9 коней (12\%), посилення у 3 (4\%). Третій тон вислуховували у 27 коней (36\%), четвертий - у 6 (8\%) досліджених нами тварин. Розщеплення першого тону реєстрували у 18 (24\%) коней, роздвоєння - у 6 (8\%). У 2 (2,7\%) коней встановлено акцент другого тону в пункті найкращої чутливості клапанів легеневої артерії.

Серцеві шуми виникають внаслідок високої швидкості або турбулентного потоку крові. Реєструються у коней із захворюваннями серця, однак вони також поширені в клінічно здорових коней. Для того, щоб визначити можливі причини шумів, їх необхідно характеризувати за локалізацією, часом появи та інтенсивністю. Якість і поширення або іррадіація шумів також використовуються для їх аналізу, але вони менш інформативні.

Локалізація шуму або місця максимального вислуховування клапанів (p.opt.) знаходяться як зліва так i справа грудної клітки, над верхівковою або основою серця. Шуми можуть поширюватися в інші ділянки грудної клітини, однак вони будуть тихішими порівняно $з$ p.opt.

Шуми можуть бути систолічними, діастолічними або безперервними (голосистолічними). Так як період діастоли, як правило, довший, ніж систоли, довжина шуму може допомогти визначити час його появи. Під час аускультації необхідно одночасно проводити пальпацію пульсу - систолічний шум збігається з артеріальним пульсом.

Серцеві шуми реєстрували у 48 із 75 спортивних коней, що складає 64\% із досліджених нами тварин. Частіше вислуховувалися систолічні шуми: в p.opt. мітрального клапана - у 15 (20\%) коней; тристулково- 
го клапана - 18 (24\%); над легеневою артерією - 6 (8\%); клапанів аорти - у 3 (4\%) тварин. Діастолічні шуми реєструвалися рідше: в р.opt. клапанів аорти - у $6(8 \%)$ спортивних коней.

Проведені дослідження дозволяють припустити, що поширення серцевих шумів у спортивних коней залежить від віку тварин, фізичного навантаження, функціональних i морфологічних змін клапанного апарату серця, що викликаються постійним впливом спортивних тренувань тощо. Однак, для підтвердження таких висновків необхідні подальші дослідження.

\section{Висновки}

1 Серцеві шуми реєструються у 64\% спортивних коней, проте більшість із них не мають клінічного значення, оскільки лише у 6,7\% досліджених тварин була знижена працездатність.

2. У спортивних коней частіше реєструються систолічні шуми (в p.opt. мітрального клапана - у 20\% коней; тристулкового клапана $-24 \%$; над легеневою артерією - 8\%; клапанів аорти - у 4\% тварин), рідше діастолічні (в p.opt. клапанів аорти - у 8\% коней).

Перспективи подальших досліджень. Вивчити поширення серцевих шумів і встановити їх клінічне значення у спортивних коней до та після фізичного навантаження.

\section{Бібліографічні посилання}

Ricketts, S.W. (2004). Hematologic and biochemical abnormalities in athletic horses, In: Equine sports medicine and surgery, $1^{\text {st }}$ edn., Elsevier, London, 949 966.

Reef, V.B., Bonagura, J.B., Buhl, R. (2014). Recommendations for management of equine athletes with cardi- ovascular abnormalities. J. Vet. Intern. Med. 28(3), 749-761.

Reef, V.B. (1995). Heart murmurs in horses: determining their significance with echocardiography. Equine Vet. J. Suppl. 19, 71-80.

Davis, J.L., Gardner, S.Y., Schwabenton, B., Breuhaus, B.A. (2002). Congestive heart failure in horses: 14 cases (1984-2001). J. Am. Vet. Med. Assoc. 220(10), $1512-1515$.

Kriz, N.G., Hodgson, D.R., Rose, R.J. (2000). Prevalence and clinical importance of heart murmurs in racehorses. J. Am. Vet. Med. Assoc. 216(9), 1441-1445.

Young, L.E., Rogers, K., Wood, J.L. (2008). Heart murmurs and valvular regurgitation in thoroughbred racehorses: epidemiology and associations with athletic performance. J. Vet. Intern. Med. 22, 418-426.

Martin, B.J., Reef, V.B., Parente, E.J., Sage, A.D. (2000). Causes of poor performance of horses during training, racing, or showing: 348 cases (1992-1996). J. Am. Vet. Med. Assoc. 216(4), 554-558.

Zucca, E., Ferrucci, F., Stancari, G. (2010). The prevalence of cardiac murmurs among standardbred racehorses presented with poor performance. J. Vet. Med. Sci. 72(6), 781-785.

Young, L.E., Wood, J.L. (2000). The effects of age and training on murmurs of atrioventricular valvular regurgitation in young Thoroughbreds. Equine Vet. J. 32(3), 195-199.

Stevens, K.B., Marr, C.M., Horn, J.N.R. (2009). Effect of left-sided valvular regurgitation on mortality and causes of death among a population of middle-aged and older horses. Veterinary Record. 164, 6-10.

Robinson, Je. (2007). Zabolevanija serdechno-sosudistoj sistemy. Bolezni loshadej. Sovremennye metody lechenija. Moskva: OOO «Akvarium-Print», 629-692 (in Russian).

Стаття надійшла до редакичї 6.10.2016 